\title{
INTERPRETASI DATA SEISMIK 2D DAN DATA SUMUR UNTUK IDENTIFIKASI MORFOLOGI JEBAKAN GAS BIOGENIK DI BARAT DAYA PERAIRAN KANGEAN
}

\author{
Tomi $^{1}$, Halasan Sihombing ${ }^{2}$, Muhardi ${ }^{1, *}$, Shaska Ramadhan Zulivandama ${ }^{3}$ \\ ${ }^{1}$ Program Studi Geofisika, Fakultas Matematika dan Ilmu Pengetahuan Alam, Universitas Tanjungpura \\ ${ }^{2}$ Program Studi Teknik Elektro, Politeknik Negeri Pontianak \\ ${ }^{3}$ Pusat Penelitian dan Pengembangan Geologi Kelautan \\ *Penulis Korespondensi : muhardi@physics.untan.ac.id
}

\begin{abstract}
Abstrak. Akumulasi minyak dan gas bumi baru-baru ini telah ditemukan di Cekungan Jawa Timur, sehingga area ini menjadi tempat yang banyak diminati untuk eksplorasi hidrokarbon di Indonesia. Penelitian ini bertujuan untuk mengidentifikasi reservoir gas biogenik di Barat Daya Perairan Kangean telah dilakukan berdasarkan data seismik refleksi 2D dan log sumur. Metode penelitian yang digunakan adalah metode analisis Direct Hydrocarbon Indicator (DHI), analisis data sumur dan interpolasi. Analisis Direct Hydrocarbon Indicator (DHI) pada data seismik refleksi 2D dilakukan dengan mengamati brightspot pada penampang seismik. Sedangkan analisis data log dilakukan dengan mengamati log densitas, log porositas neutron, log gamma ray, dan log resistivitas batuan. Struktur bawah permukaan dasar Perairan Kangean terdiri dari Formasi Mundu dan Formasi Lidah. Formasi Mundu terdiri dari Formasi Paciran Sandstones dan Formasi Paciran Limestones, tersusun atas batupasir dan batugamping yang berporositas besar sehingga dapat mengalirkan dan menyimpan gas biogenik. Formasi Lidah tersusun atas batu lempung biru masif yang berporositas kecil sehingga berperan sebagai batuan penutup. Hasil penelitian menunjukkan bahwa daerah di sekitar Formasi Paciran Limestones ditemukan struktur patahan maupun lipatan berupa sinklin dan antiklin. Antiklin pada Formasi Paciran Limestones merupakan jebakan tempat gas biogenik terakumulasi. Morfologi jebakan mempunyai puncak yang terletak pada kedalaman $650 \mathrm{~m}$ di bawah permukaan dasar perairan, dan diduga memiliki dimensi sekitar $18 \mathrm{~km} \times 6 \mathrm{~km}$ dengan ketebalan formasi sekitar 180 hingga $240 \mathrm{~m}$.
\end{abstract}

Kata Kunci: gas biogenik; Kangean; morfologi jebakan; seismik refleksi

\begin{abstract}
Oil and gas accumulations have recently been discovered in the East Java Basin, making this area a highly desirable hydrocarbon exploration area in Indonesia. This study aims to identify a biogenic gas reservoir in the Southwest of Kangean Waters based on 2D seismic reflection data and well logs. The study method used is the Direct Hydrocarbon Indicator (DHI) analysis method, well data analysis, and interpolation. The Direct Hydrocarbon Indicator (DHI) study on 2D reflection seismic data was conducted by observing the bright spot in the seismic section. Meanwhile, log data analysis was performed by following density logs, neutron porosity logs, gamma-ray logs, and rock resistivity logs. The sub-surface structure of the Kangean waters consisted of the Mundu Formation and the Lidah Formation. The Mundu Formation consists of the Paciran Sandstones Formation and the Paciran Limestones Formation, composed of sandstones and limestones with large porosity to flow and store biogenic gas. The Lidah Formation is composed of massive blue clay rock with a minor porosity so that it acts as a cover rock. The results showed that the Paciran Limestones Formation area found fault and fold structures in syncline and anticline. The anticline in the Paciran Limestones Formation is a trap where biogenic gas accumulates. The trap's morphology has a peak located at a depth of $650 \mathrm{~m}$ below the water bed's surface and is thought to have dimensions of about $18 \mathrm{~km} \times 6 \mathrm{~km}$ with a formation thickness of about 180 to $240 \mathrm{~m}$.
\end{abstract}

Keywords: biogenic gases; Kangean; trap morphology; reflection seismic

\section{PENDAHULUAN}

Indonesia merupakan salah satu negara berkembang dengan konsumsi energi yang meningkat setiap tahun dalam menopang pertumbuhan ekonomi. Hingga tahun 2016, simulasi penyediaan BBM dianggap dapat memenuhi kebutuhan nasional, sedangkan pada tahun 2017 hingga 2025 penyediaan BBM dianggap tidak akan mampu lagi memenuhi kebutuhan nasional (Sa'adah dkk., 2017). Oleh sebab itu, untuk menghindari krisis energi pada masa yang akan datang, harus ada terobosan yang tepat dalam rangka memenuhi 
kebutuhan nasional terhadap energi. Salah satu gagasan yang dapat diterapkan adalah kegiatan eksplorasi minyak dan gas bumi (Lestari dkk., 2017) dan mengoptimalkan energi-energi alternatif (Purnama dkk., 2020).

Cadangan gas dunia diperkirakan 20-30\% merupakan gas biogenik, sementara di Indonesia yang baru ditemukan adalah sebesar 3,8\% dari total 104 trillion cubic feet (TCF) gas cadangan Indonesia. Gas biogenik di Indonesia tersebut masih banyak yang belum ditemukan (Tomi dkk., 2020). Gas biogenik ini terbentuk pada ekosistem lautan yang relatif dangkal (Alfatih dkk., 2017). Besarnya potensi gas biogenik ini merupakan solusi energi alternatif untuk mengganti energi konvensional yang telah lama digunakan (Putri dkk., 2016).

Akumulasi minyak dan gas yang signifikan telah ditemukan baru-baru ini di Cekungan Jawa Timur, membuat area ini menjadi tempat yang banyak diminati untuk eksplorasi hidrokarbon di Indonesia (Satyana dan Purwaningsih, 2003). Contohnya pada sumur bor yang terletak di perairan Bali sebelah utara yaitu pada sumur Terang-1 ditemukan indikasi potensi adanya keberadaan gas biogenik yang terdapat pada Formasi Mundu dengan kedalaman sekitar 600 hingga 700 meter dan berada di bawah permukaan dasar laut dengan sebaran hingga ke arah tenggara Pulau Kangean (Dikman dkk., 2015).
Salah satu metode yang digunakan untuk eksplorasi hidrokarbon adalah metode seismik refleksi dan log sumur. Metode seismik refleksi mencitrakan bawah permukaan dengan resolusi tinggi dan penetrasi yang dalam (Sismanto, 2016). Metode seismik refleksi ini memiliki resolusi yang baik ke arah horizontal (Everett, 2013), tetapi kurang baik ke arah vertikal (Telford dkk., 1990), sedangkan log sumur memiliki resolusi yang baik ke arah vertikal tetapi buruk ke arah horizontal, sehingga penggabungan dari kedua metode ini dibutuhkan untuk menghasilkan pencitraan bawah permukaan yang lebih baik (Dikman dkk., 2015).

Gas biogenik dapat dijadikan salah satu solusi dalam mengatasi krisis energi nasional. Pada Perairan Kangean terindikasi ada gas biogenik dan citra bawah permukaan akan lebih baik dengan menggabungkan data seismik refleksi dan log sumur. Oleh sebab itu, penulis bermaksud melakukan penelitian dengan tujuan untuk menge-tahui bagaimana struktur lapisan bawah permuka-an di barat daya Perairan Kangean dan mencitrakan morfologi reservoir gas biogeniknya. Lokasi barat daya perairan Kangean dipilih karena lokasi ini lebih dekat dengan sumur Terang-1 dan Batur-1.

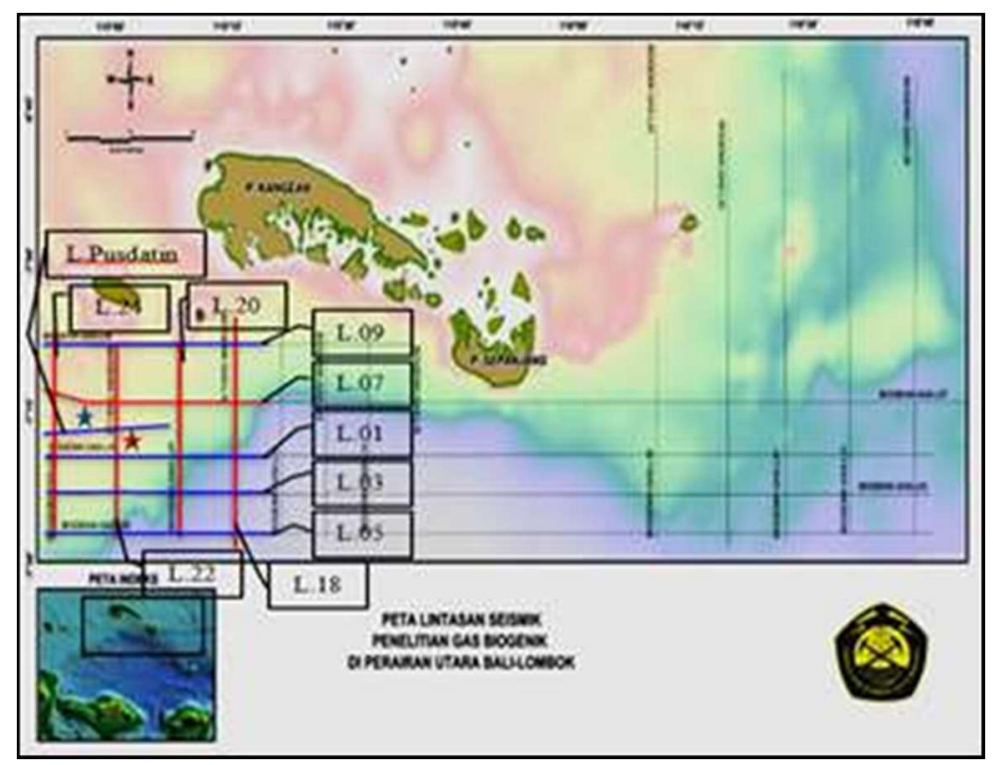

Gambar 1. Peta lokasi penelitian. Garis merah merupakan lintasan pada pengolahan data (L07, L18, L20, L22 dan L24), garis biru: lintasan pendukung (L.Pusdatin, L01, L03, L05 dan L09), bintang biru: Sumur Terang-1 dan bintang merah: Sumur Batur-1 (Sumber: PPPGL, tidak dipublikasi). 


\section{METODOLOGI}

Secara administrasi lokasi penelitian ter-letak di utara Bali yaitu termasuk Provinsi Bali dan secara geografis terletak pada koordinat $114^{\circ} 51^{\prime}$ hingga $115^{\circ} 16^{\prime}$ Bujur Timur dan $-07^{\circ} 07^{\prime}$ hingga $-07^{\circ} 25^{\prime}$ Lintang Selatan. Adapun luas lokasi penelitian diperkirakan sekitar $1.500 \mathrm{~km}^{2}$.

Data yang telah diolah dalam penelitian ini adalah data seismik 2D multichannel dengan nama lintasan L07, 18, 20, 22, dan L24 hasil akuisisi dari PPPGL (Pusat Penelitian dan Pengembangan Geologi Kelautan), data sumur, data checkshot, marker formasi, master log dan laporan sumur (well report) di area penelitian (yaitu sumur Batur-1 dan Terang1) yang didapat dari PPPGL, seperti pada Gambar 1. Data pendukung yang digunakan yaitu penampang hasil stacking seismik 2D multichannel lintasan L01, 03, 05 dan L09 hasil olahan PPPGL serta 1 data penampang seismik hasil olahan Pusat Data dan Informasi (L.Pusdatin) dari PPPGL.

Pada penelitian ini dilakukan 5 tahapan prosedur kerja. Adapun tahapan tersebut yaitu studi literatur, persiapan alat dan bahan, pengolahan data mentah seismik, identifikasi struktur formasi interest (target) dan interpretasi daerah jebakan (akumulasi) gas biogenik, seperti yang disajikan pada Gambar 2 hingga 4. Perangkat lunak (software) yang dipakai yaitu ProMAX-5000 untuk pengolahan data seismik, perangkat lunak pengolahan data sumur dan

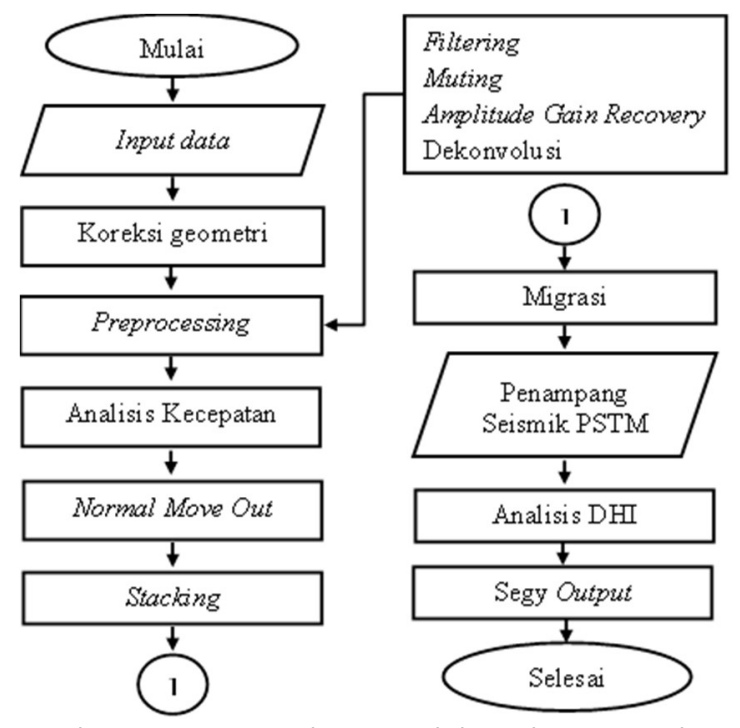

Gambar 2. Diagram alir pengolahan data seismik 2D perangkat lunak Petrel untuk interpretasi. Proses pengolahan data mentah seismik disajikan pada Gambar 2, sedangkan identifikasi struktur formasi interest disajikan pada Gambar 3.

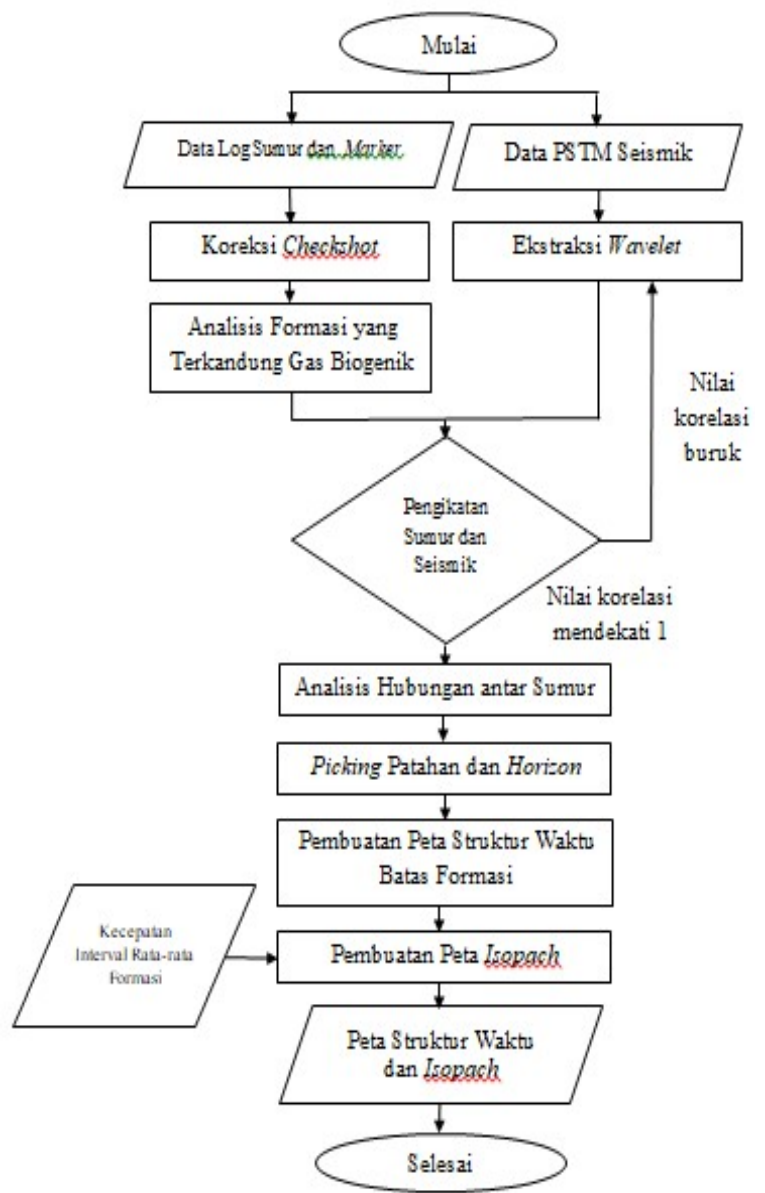

Gambar 3. Diagram alir interpretasi data seismik korelasi dengan data sumur untuk identifikasi zona target

\section{HASIL DAN PEMBAHASAN \\ Korelasi Antar Sumur pada Penampang Seismik}

Gambar 4 merupakan interpretasi batas atas dan bawah Formasi Mundu pada penampang seismik L.Pusdatin. Batas tersebut diperoleh berdasarkan hasil pengikatan dengan Sumur Terang-1. Sumur ini berjarak $1550 \mathrm{~m}$ dari lintasan L.Pusdatin. Kurva berwarna hitam merupakan kurva log Gamma Ray (GR). Garis vertikal tipis berwarna biru merupakan gambar lintasan sumur (wellpath). Titik berwarna hijau dan kuning berturut-turut merupa-kan batas atas dan bawah Formasi Paciran Limestones pada lintasan seimik yang berpotongan (yaitu L.22). 


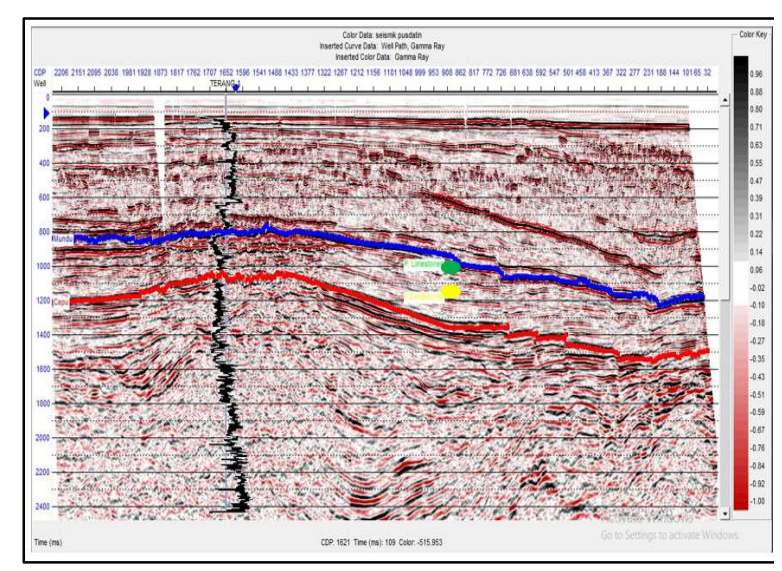

Gambar 4. Interpretasi batas Formasi Mundu pada penampang L.Pusdatin

Formasi Mundu pada Gambar 4 memiliki nilai log Gamma Ray lebih rendah dibanding formasi di atasnya (Formasi Lidah). Log GR rendah ini menunjukkan kandungan serpih yang lebih sedikit dan porositas yang lebih tinggi. Berdasarkan analisis crossover log porositas dan log densitas serta nilai resistivitas yang besar (Gambar 5) maka diketahui jenis hidrokarbon yang terkandung di Formasi ini adalah gas (Linzai dkk., 2016). Gas ini diketahui merupakan gas biogenik (Satyana dan Purwaningsih, 2003).

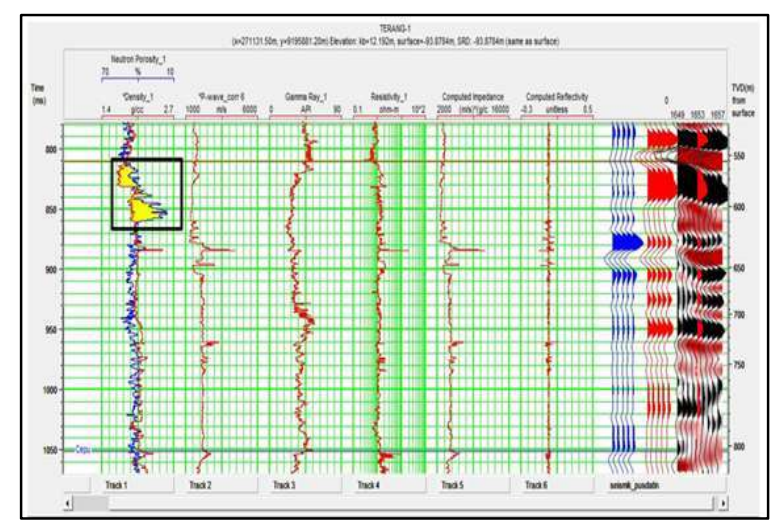

Gambar 5. Pengikatan data sumur Terang-1 dan seismik L.Pusdatin, menghasilkan korelasi maksimum sebesar 0,514. Terdapat DHI berupa crossover log porositas dan log densitas (kotak hitam) pada Formasi Mundu

Gambar 6 merupakan interpretasi batas atas dan bawah Formasi Paciran Limestones pada penampang seismik L.22. Batas tersebut diperoleh berdasarkan hasil pengikatan dengan Sumur Batur-1. Sumur ini berjarak $460 \mathrm{~m}$ dari lintasan L.22 dan berjarak 10,8 km dari sumur Terang-1. Titik berwarna biru dan merah berturut-turut merupakan batas atas dan bawah Formasi Mundu pada lintasan seimik yang berpotongan (L.Pusdatin). Gambar tersebut memperjelas bahwa Formasi Paciran Limestones dan Formasi Paciran Sandstones merupakan bagian dari Formasi Mundu.

Formasi Paciran Limestones pada Gambar 6 memiliki nilai log Gamma Ray lebih rendah dibanding formasi di atasnya. Hal ini menunjukkan porositas formasi ini lebih tinggi daripada porositas formasi di atasnya. Berdasarkan analisis crossover log porositas dan log densitas serta nilai resistivitas yang besar (Gambar 7) maka diketahui jenis hidrokarbon yang terkandung di formasi ini adalah berupa gas (Mayasari dkk., 2019). Gas ini diketahui merupakan gas biogenik berdasarkan studi geokimia (Livsey dan Amar, 1995).

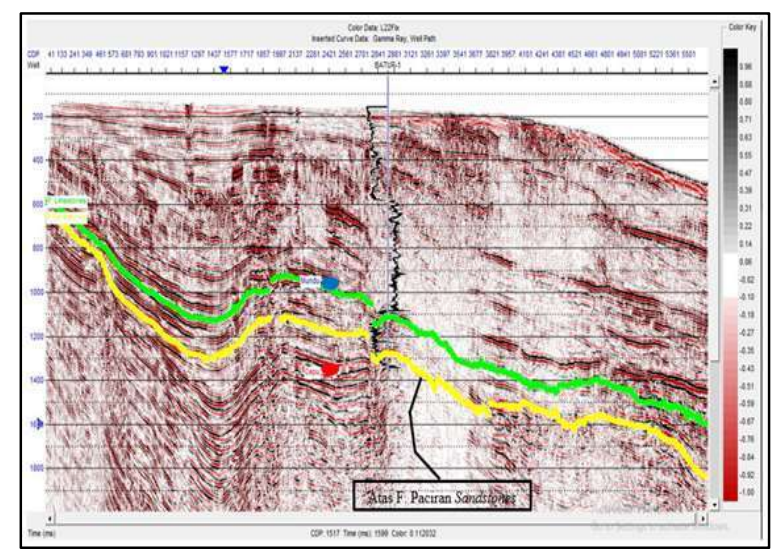

Gambar 6. Interpretasi batas Formasi Paciran Limestones penampang L.22

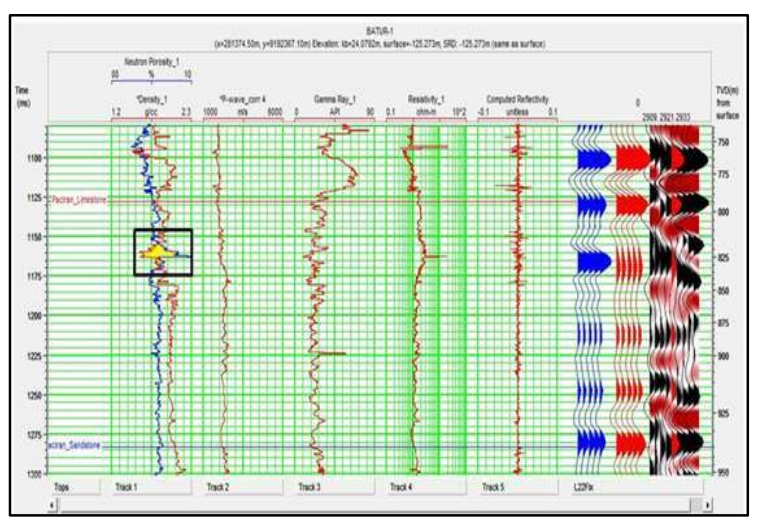

Gambar 7. Pengikatan data sumur Batur-1 dan seismik L.22, menghasilkan korelasi maksimum sebesar 0,642. Terdapat DHI berupa crossover log porositas dan log densitas (kotak hitam) pada Formasi Paciran Limestones. 


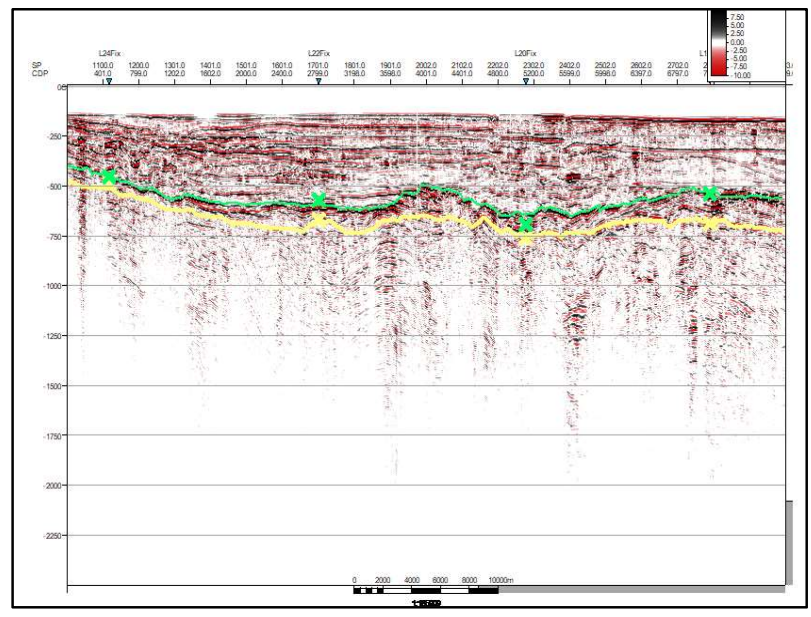

(a)

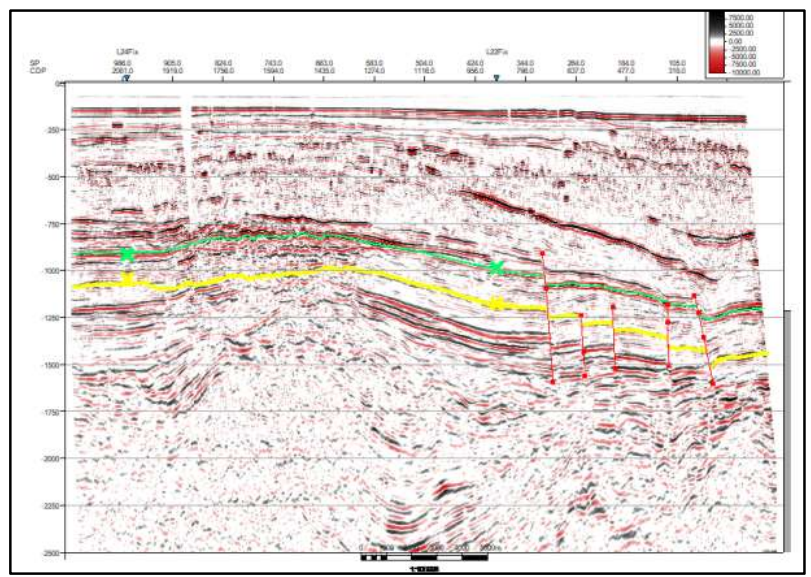

(c)

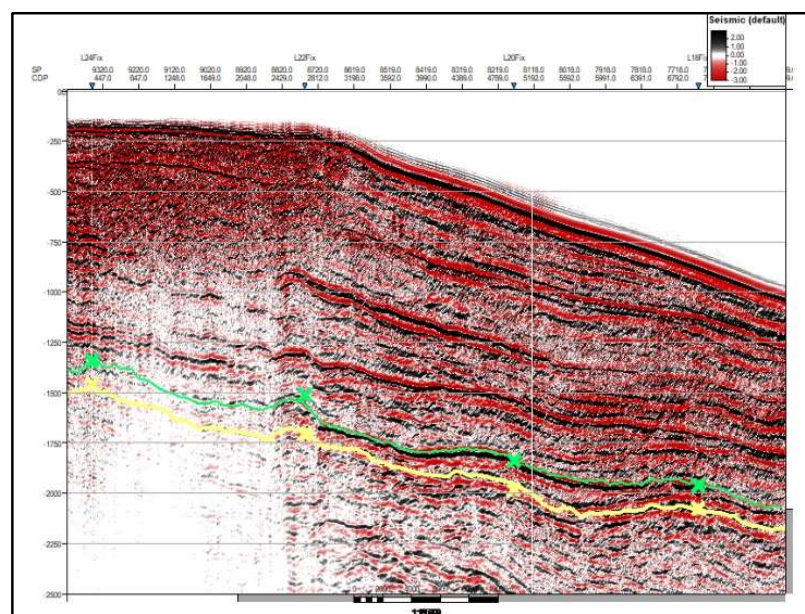

(e)

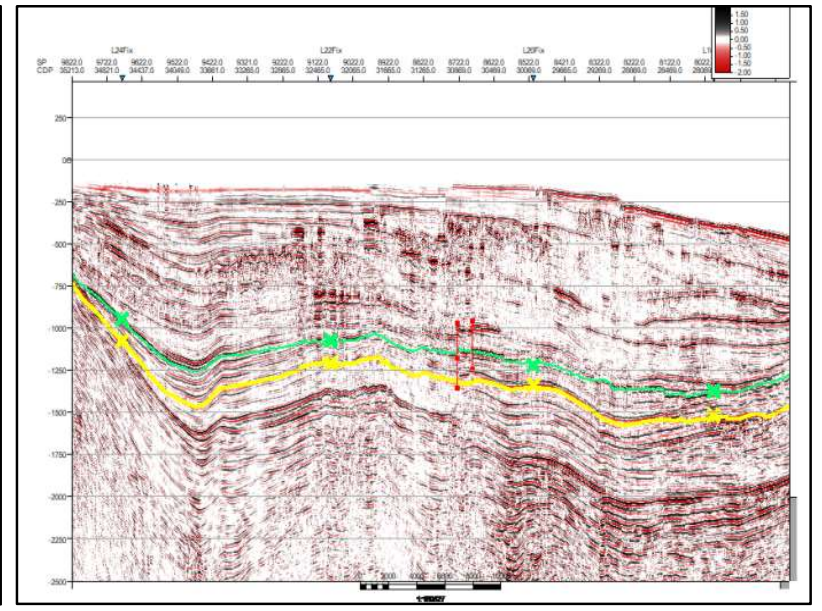

(b)

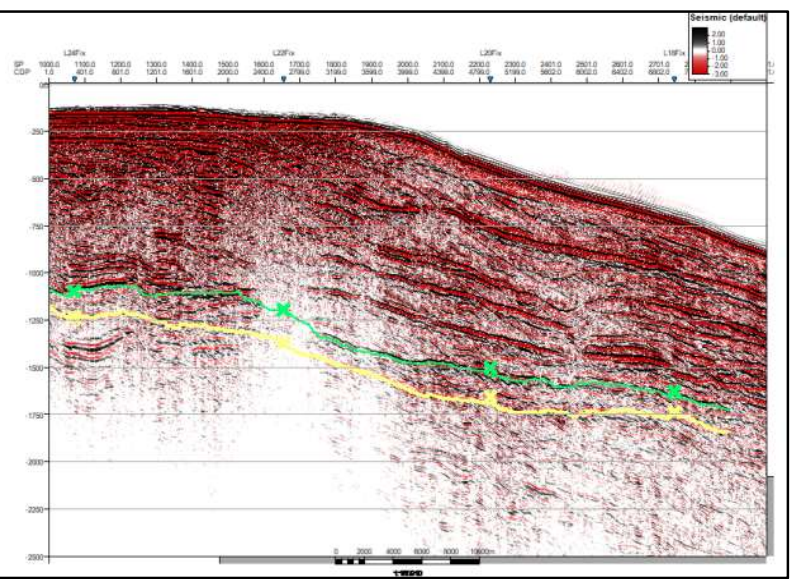

(d)

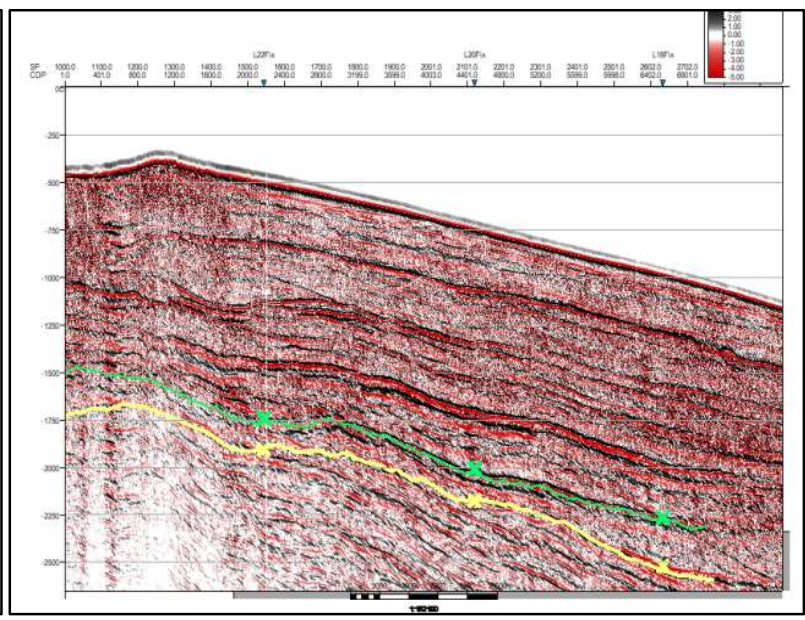

(f)

Gambar 8. Interpretasi batas Paciran Limestones penampang berarah B-T: (a) L.09 (b) L.07 (c) L.Pusdatin (d) L.01 (e) L.03 dan (f) L.05 


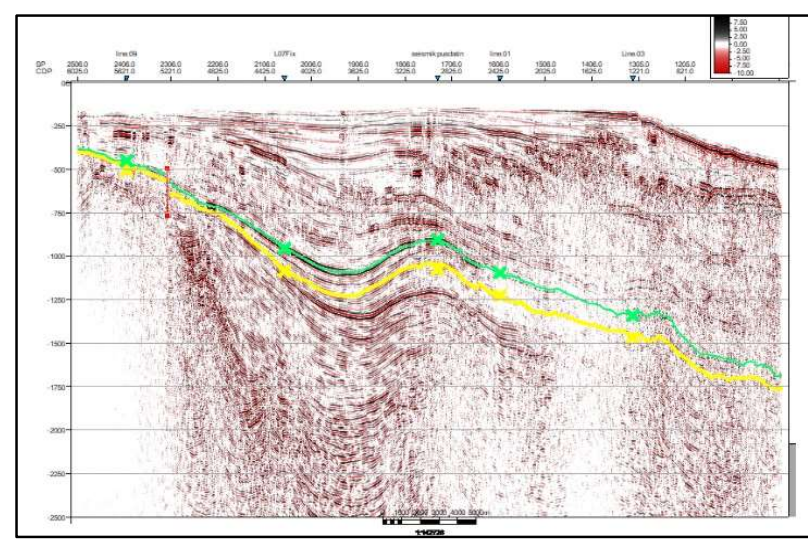

(a)

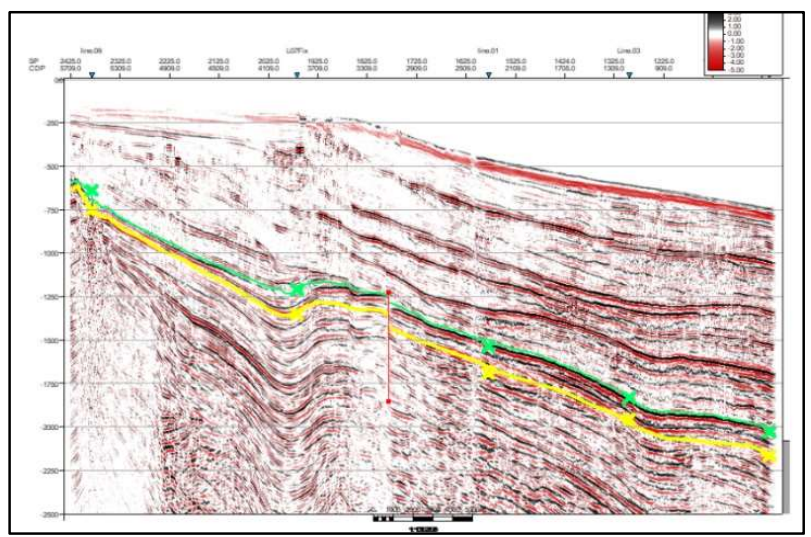

(c)

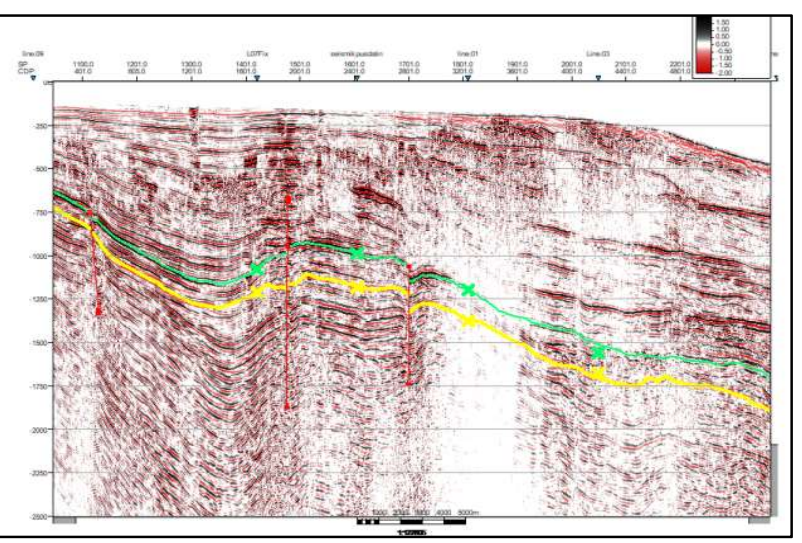

(b)

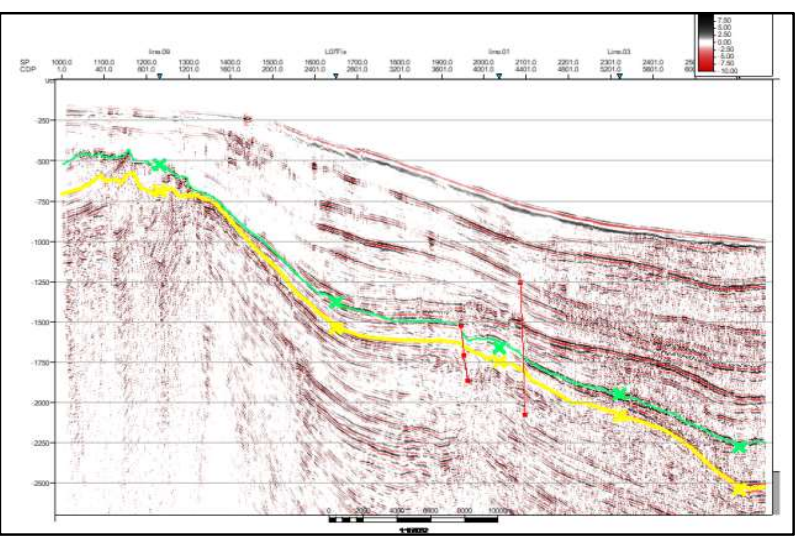

(d)

Gambar 9. Interpretasi batas Paciran Limestones penampang berarah U-S: (a) L.24 (b) L.22 (c) L.20 (d) L.18

Formasi Paciran Limestones merupakan formasi yang cocok menjadi reservoir gas biogenik. Formasi berlitologi batugamping ini merupakan formasi yang berada di antara Formasi Lidah dan Formasi Paciran Sandstones. Formasi Lidah berlitologi batulempung biru masif dengan porositas kecil sehingga dapat bertindak sebagai batuan penutup. Formasi Paciran Sandstones berlitologi batu pasir dengan porositas besar sehingga dapat melewatkan gas biogenik ke formasi di atasnya (Formasi Paciran Limestones).

Berdasarkan uraian di atas, formasi interest akumulasi gas biogenik lebih tepat diidentifikasi pada Formasi Paciran Limestones. Hal tersebut dikarenakan ketebalan Formasi Paciran Limestones lebih tipis daripada ketebalan Formasi Mundu. Ketebalan yang lebih tipis tersebut merupakan daerah yang memiliki DHI berdasarkan korelasi antarsumur.

\section{Interpretasi Patahan dan Horizon Interest}

Gambar 8 merupakan interpretasi patahan dan batas atas-bawah formasi Paciran Limestones pada penampang seismik berarah Barat-Timur. Garis berwarna hijau dan kuning berturut-turut merupakan batas atas dan bawah formasi. Tanda silang ( $\mathrm{x}$ ) merupakan posisi batas atas dan bawah formasi di lintasan yang berpotongan dengan penampang. Garis vertikal berwarna merah merupakan hasil interpretasi patahan/sesar di penampang seismik.

Struktur di Formasi Paciran Limestones pada penampang seismik berarah Barat-Timur telah diidentifikasi. Identifikasi tersebut dilakukan dengan melihat kemenerusan sekuen seismik dan respon amplitudo seismiknya. Diketahui struktur berupa antiklin dan patahan terdapat pada L.07 dan L.Pusdatin. Patahan pada L.Pusdatin ini merupakan sesar normal.

Gambar 9 merupakan interpretasi patahan dan batas atas-bawah Formasi Paciran Limestones pada penampang seismik berarah Utara-Selatan. Diketahui struktur berupa sinklin dan antiklin 
(pelipatan) terdapat pada L.24, L.22 dan L.20, sedangkan patahan terdapat di semua lintasan berarah Utara-Selatan ini. Struktur berupa sinklin dan antiklin ini diakibatkan oleh gaya kompresi dari Utara-Selatan (Setiady dkk., 2018).

\section{Analisis Morfologi Jebakan Gas Biogenik}

Gambar 10 merupakan struktur atas Formasi Paciran Limestones dalam 3D dilihat dari atas. Struktur atas formasi ini dari Utara ke Selatan cenderung mengalami peningkatan kedalaman. Akan tetapi berbeda dengan sisi barat daerah penelitian. Pada sisi barat ini terdapat anomali struktur berupa pelipatan (Gambar 11) yang terdiri dari sinklin dan antiklin.

Struktur antiklin merupakan salah satu jebakan hidrokarbon tempat gas terakumulasi. Hal tersebut diakibatkan oleh sifat gas yang selalu mencari tempat lebih tinggi dari sekitarnya akibat massa jenis gas yang lebih kecil dari massa jenis minyak, air maupun batuan di sekitarnya. Gas yang merupakan fluida tersebut mengalir dari berbagai arah hingga akhirnya terjebak pada jebakan hidrokarbon. Lokasi jebakan ini dapat dilihat pada Gambar 12.

Struktur atas dan bawah Formasi Paciran Limestones memiliki pola yang hampir sama. Hal tersebut diketahui dengan membandingkan Gambar 12 dan 13. Stuktur atas memiliki variasi nilai two way time (twt) dari -300 hingga -2500 ms sedangkan struktur bawahnya dari -300 hingga -2700 ms. Hasil pengurangan dari twt struktur atas dan struktur bawah ini menghasilkan peta isokron.

Gas biogenik di Perairan Kangean terakumulasi pada struktur jebakan antiklin. Luasan struktur antiklin ini ditandai seperti yang ditunjukkan pada

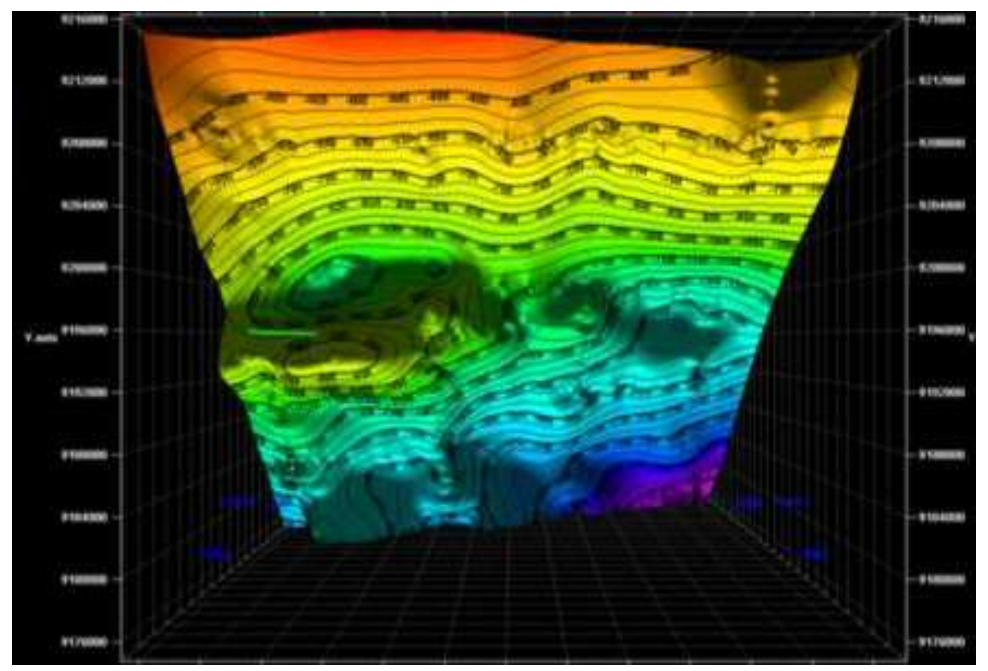

Gambar 10. Struktur atas Paciran Limestones dalam 3D dilihat dari atas

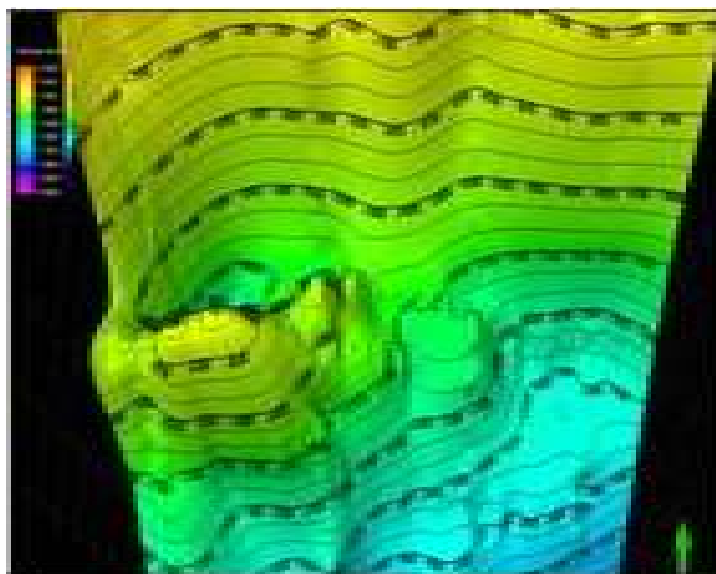

(a)

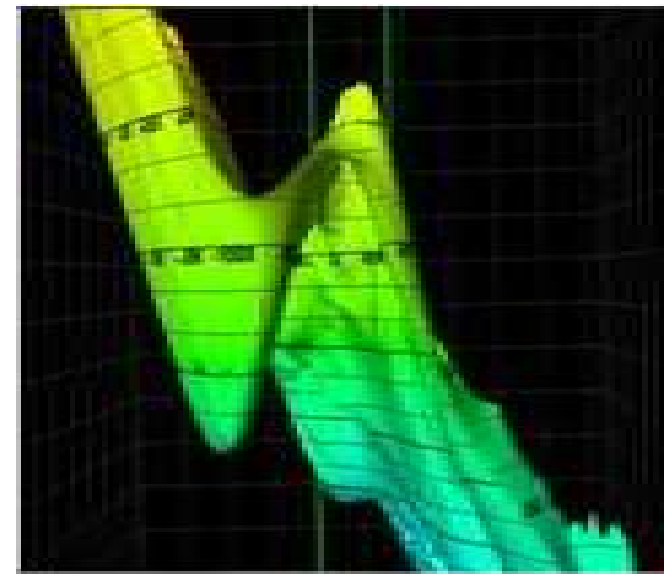

(b)

Gambar 11. Struktur antiklin dalam 3D pada struktur atas Paciran Limestones: (a) dilihat dari atas (b) dilihat dari arah Barat 
Gambar 14 dengan ketebalan formasi ditunjukkan pada Gambar 15. Dari Gambar 14 dan 15 ini diketahui dimensi jebakan adalah sekitar $18 \mathrm{~km} \times 6$ $\mathrm{km}$ dengan ketebalan formasi interest sekitar 180 hingga $240 \mathrm{~m}$. Puncak antiklin berada pada koordinat UTM $50 S \mathrm{x}=9194000$ dan $\mathrm{y}=274000$ di twt $-800 \mathrm{~ms}$ atau sekitar $650 \mathrm{~m}$ di bawah permukaan perairan. Kedalaman ini diperoleh berdasarkan pengikatan dengan sumur Terang-1. Gambar 15 merupakan peta isopach yang diperoleh dari hasil perkalian antara peta isokron dengan setengah dari kecepatan interval rata-rata di formasi Paciran Limestones (yaitu setengah dari $2240 \mathrm{~m} / \mathrm{s}$ ). Nilai kecepatan interval rata-rata tersebut didapat dari data log sonik.

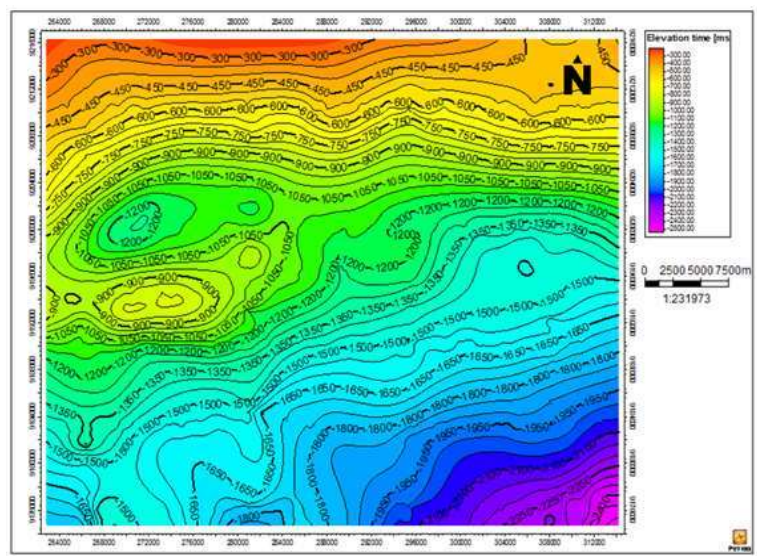

Gambar 12. Peta struktur atas Formasi Paciran Limestones

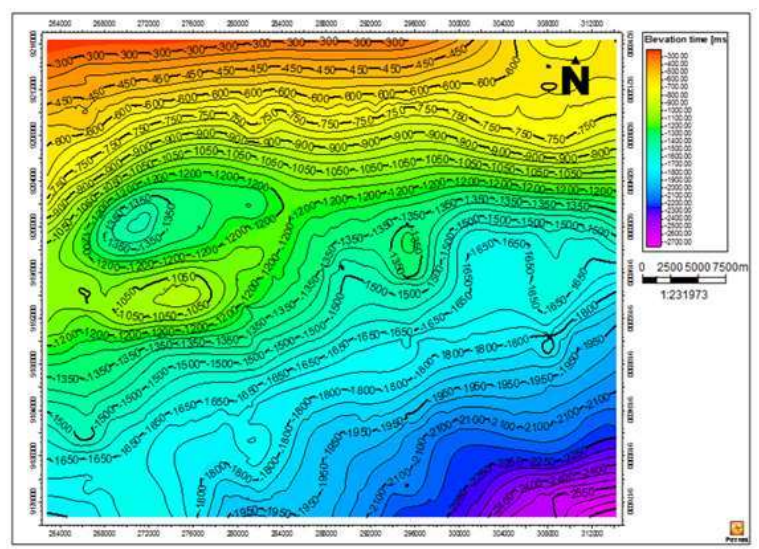

Gambar 13. Peta struktur atas Formasi Paciran Limestones

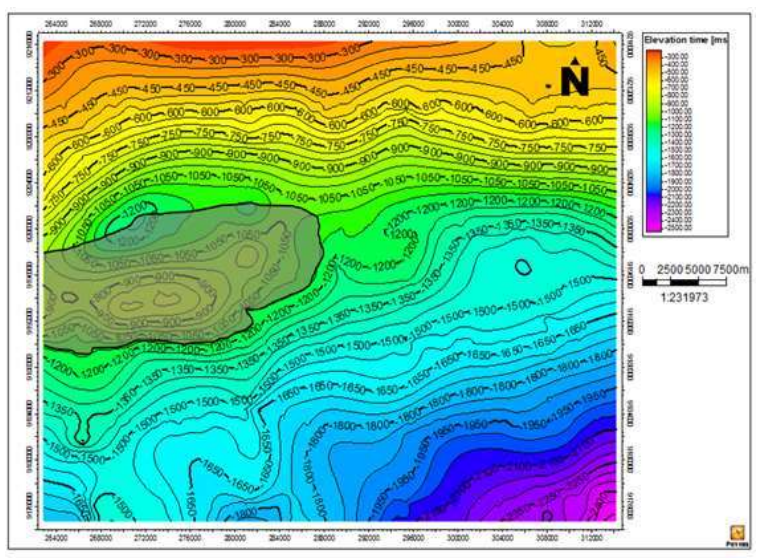

Gambar 14. Area jebakan gas biogenik sesuai analisis penulis

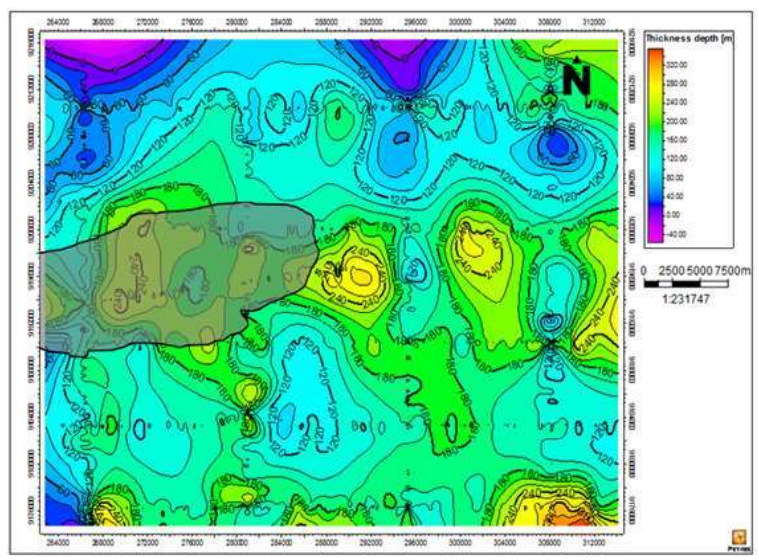

Gambar 15. Peta isopach Formasi Paciran Limestones

Struktur atas dan bawah Formasi Paciran Limestones memiliki pola yang hampir sama. Hal tersebut diketahui dengan membandingkan Gambar 12 dan 13. Stuktur atas memiliki variasi nilai two way time (twt) dari -300 hingga $-2500 \mathrm{~ms}$ sedangkan struktur bawahnya dari -300 hingga $-2700 \mathrm{~ms}$. Hasil pengurangan dari twt struktur atas dan struktur bawah ini menghasilkan peta isokron.

Gas biogenik di Perairan Kangean terakumulasi pada struktur jebakan antiklin. Luasan struktur antiklin ini ditandai seperti yang ditunjukkan pada Gambar 14 dengan ketebalan formasi ditunjukkan pada Gambar 15. Dari Gambar 14 dan 15 ini diketahui dimensi jebakan adalah sekitar $18 \mathrm{~km} \times 6$ $\mathrm{km}$ dengan ketebalan formasi interest sekitar 180 hingga $240 \mathrm{~m}$. Puncak antiklin berada pada koordinat UTM 50S $x=9194000$ dan $y=274000$ di twt $-800 \mathrm{~ms}$ atau sekitar $650 \mathrm{~m}$ di bawah permukaan perairan. Kedalaman ini diperoleh berdasarkan pengikatan dengan sumur Terang-1. Gambar 15 merupakan peta 
isopach yang diperoleh dari hasil perkalian antara peta isokron dengan setengah dari kecepatan interval rata-rata di formasi Paciran Limestones (yaitu setengah dari $2240 \mathrm{~m} / \mathrm{s}$ ). Nilai kecepatan interval rata-rata tersebut didapat dari data log sonik.

\section{PENUTUP}

\section{Simpulan dan Saran}

Simpulan yang dapat diambil berdasarkan penelitian yang telah dilakukan adalah bahwa struktur bawah permukaan dasar Perairan Kangean terdiri dari Formasi Mundu dan Formasi Lidah. Formasi Mundu terdiri dari Formasi Paciran Sandstones dan Formasi Paciran Limestones. Formasi Paciran Sandstones dan Limestones ini terdiri dari batupasir dan batugamping yang berporositas besar sehingga dapat mengalirkan dan menyimpan gas biogenik. Formasi Lidah mengandung batu lempung biru masif yang berporositas kecil sehingga dapat bertindak sebagai batuan penutup. Dapat diketahui juga pada daerah di sekitar Formasi Paciran Limestones terdapat struktur berupa patahan dan pelipatan yang terdiri dari sinklin dan antiklin. Gas biogenik di Perairan Kangean terakumulasi pada struktur jebakan antiklin Formasi Paciran Limestones. Morfologi jebakan mempunyai puncak yang terletak pada kedalaman $650 \mathrm{~m}$ di bawah permukaan dasar perairan, dan diduga memiliki dimensi sekitar $18 \mathrm{~km}$ $x 6 \mathrm{~km}$ dengan ketebalan formasi sekitar 180 hingga $240 \mathrm{~m}$.

Dalam penelitian selanjutnya, disarankan untuk menambah data dengan memperbanyak lintasan terutama berarah Timur Laut - Barat Daya dan Tenggara - Barat Laut, agar morfologi yang digambarkan semakin baik. Selain itu, perlu juga melakukan analisis geokimia terhadap lapisan batuan yang diduga sebagai jebakan gas biogenik agar diketahui potensi yang terkandung di dalamnya.

\section{DAFTAR PUSTAKA}

Alfatih, I.Z., Warnana, D.D. dan Wijaya, P.H. (2017), "Seismik Fasies Modelling Pada Reservoar Gas
Biogenik: Studi Kasus Pada Lapangan "TG"", Jurnal Geosaintek, Vol.3, No.1, hal. 65-74. http://doi.org/10.12962/j25023659.v3i1.2958.

Dikman, T., Susilo, A. dan Sabbeq, S. (2015), "Korelasi Data Log Sumur dan Seismik untuk Penyebaran Litologi dan Porositas Reservoir Hidrokarbon Formasi Gumai Cekungan Sumatera Selatan", Natural-B, Vol.3, hal. 166-174. http://doi.org/10.21776/ub.naturalb.2015.003.02.10.

Everett, M.E. (2013), Near-Surface Applied Geophysics, Cambridge University Press, Cambridge. http://doi.org/10.1017/CBO9781139088435.

Lestari, P.R., Warnana, D.D. dan Marianto, F. (2017), "Karakterisasi Reservoir Karbonat Dengan Menggunakan Metode AVO Inversi Studi Kasus Lapangan "Ngawen"", Jurnal Geosaintek, Vol.3, No.2, hal. 121-126. http://doi.org/10.12962/j25023659.v3i2.2968.

Linzai, N., Syaifuddin, F. dan Widodo, A. (2016), "Analisis Perbandingan Antara Respon Seismik Sintetik Pp Dan Ps Berdasarkan Pemodelan Substitusi Fluida Pada Sumur", Jurnal Geosaintek, Vol.2, No.2, hal. 57-62. http://doi.org/10.12962/j25023659.v2i2.1917.

Livsey, A.R. dan Amar, M.S. (1995), Batur-1 Well East Java Sea A Petroleum Geochemical Evaluation of The Interval 1500' to 4279', PT. Roberston Utama Indonesia, Jakarta.

Mayasari, V., Ivansyah, O. dan Firdaus, Y. (2019), "Identifikasi Keberadaan Gas Hidrat Menggunakan Bottom Simulating Reflector Pada Penampang Seismic 2D Di Cekungan Aru, Papua Barat", POSITRON, Vol.9, No.2, hal. 61-68. http://doi.org/10.26418/positron.v9i2.33303.

Purnama, D.I., Putra, Y.S., Muhardi, M., Hayati, N. dan Triwerdhana, A. (2020), "Identifikasi Potensi Batuan Induk pada Formasi Santul di Sub-Cekungan Tarakan, Kalimantan Utara", PRISMA FISIKA, Vol.8, No.1, hal. 14. http://doi.org/10.26418/pf.v8i1.39637.

Putri, N.A., Warnana, D.D. dan Wijaya, P.H. (2016), "Karakterisasi Reservoir Gas Biogenik Pada Lapangan "TG" Dengan Menggunakan Atribut Inversi IA Dan Dekomposisi Spektral", Jurnal Geosaintek, Vol.2, No.2, hal. 99-106. http://doi.org/10.12962/j25023659.v2i2.1923. 
Sa'adah, A.F., Fauzi, A. dan Juanda, B. (2017), "Peramalan Penyediaan Dan Konsumsi Bahan Bakar Minyak Indonesia Dengan Model Sistem Dinamik", Jurnal Ekonomi dan Pembangunan Indonesia, Vol.17, No.2, hal.

http://doi.org/10.21002/jepi.v17i2.661.

Satyana, A.H. dan Purwaningsih, M.E.M. (2003), "Geochemistry of the East Java Basin: New Observations on Oil Grouping, Genetic Gas Types and Trends of Hydrocarbon Habitats", Indonesian Association of Geologist, http://doi.org/10.29118/IPA.831.03.G.021.

Setiady, D., Astawa, I.N., Hermansyah, G.M., Lugra, I.W. dan Nainggolan, T.B. (2018), "Stratigrafi Perairan Utara Bali Dari Hasil Interpretasi Seismik 2D", Jurnal Geologi Kelautan, Vol.15, No.2, hal. 95-106. http://doi.org/10.32693/jgk.15.2.2017.349.

Sismanto (2016), Pengantar Survei dengan Menggunakan Gelombang Seismik, Gerbang Media Aksara, Yogyakarta.

Telford, W.M., Geldart, L.P. dan Sheriff, R.E. (1990), Applied Geophysics, 2 Ed., Cambridge University Press, Cambridge.

http://doi.org/10.1017/CBO9781139167932.

Tomi, T., Sihombing, H. dan Muhardi, M. (2020), "Pencitraan Struktur Bawah Permukaan Dasar Perairan Kangean Menggunakan Data Seismik Refleksi 2D Multichannel", PRISMA FISIKA, Vol.7, No.3, hal. 203-208. http://doi.org/10.26418/pf.v7i3.36516. 